\title{
PENGARUH VISUALISASI IKLAN TV TERHADAP KEPUTUSAN PEMBELIAN MAKANAN “PRODUK INDOFOOD” PADA MASYARAKAT DESA NGREDEN KECAMATAN WONOSARI KABUPATEN KLATEN
}

\author{
Adam Wijoseno', \\ Manajemen, Fakultas Ekonomi dan Bisnis Universitas Tunas Pembangunan Surakarta \\ Sri Wijiastuti ${ }^{2}$, \\ Manajemen, Fakultas Ekonomi dan Bisnis Universitas Tunas Pembangunan Surakarta \\ Agus Purwanto ${ }^{3}$, \\ Manajemen, Fakultas Ekonomi dan Bisnis Universitas Tunas Pembangunan Surakarta
}

\begin{tabular}{l} 
Info Artikel \\
\hline Kata kunci: \\
Visualisasi Iklan, Isi \\
Pesan, Format \\
Pesan, \\
Sumberpesan, \\
Keputusan \\
Pembelian, Regresi \\
Linier Causal Step \\
Alamat korespondensi : \\
Adam Wijoseno \\
E-mail: \\
(adamwijoseno18@gmail \\
.com)
\end{tabular}

\section{PENDAHULUAN}

Untuk membuat konsumen membeli produk yang ditawarkan maka dibutuhkan adanya promosi seperti iklan yang menarik dan efektif. Menurut Kotler dan Keller (2016: 528), adversiting is any paid from nonpersonal presentation and promotion of ideas, goods or services by an indetified sponsor atau iklan adalah setiap bayaran dari presentasi nonpersonal dan promosi ide, barang atau jasa oleh sponsor yang teridentifikasi.

Promosi iklan yang ditawarkan akan mempengaruhi minat konsumen untuk mencoba mengkonsumsi produk tersebut. Beriklan di televisi juga merupakan salah satu bentuk promosi yang dilakukan oleh perusahaan. Setelah melihat promosi iklan yang menarik di televisi, tentunya konsumen akan penasaran dan akhirnya mencoba produk yang terdapat pada iklan tersebut. Setiap perusahaan termasuk PT. Indofood yang mengeluarkan biaya untuk iklannya tentu menginginkan keuntungan sesuai dengan yang mereka keluarkan, dan tujuan masing-masing perusahaan untuk memasarkan produknya adalah sama yaitu penjualan di masa yang akan datang.

Indikator - indicator yang dapat digunakan untuk mengukur variabel 
periklanan menurut Kotler dan Armstrong (2014: 157) sebagai berikut :

1) Penemuan informasi tentang produk atau perusahaan dari berbagai media mudah. 2) Design media yang digunakan menarik. 3) Informasi yang disampaikan dalam berbagai media jelas. 4) Pesan yang terkandung dalam berbagai media dapat di percaya.

Tujuan penelitian yaitu :

1. Untuk menguji dan mengukur pengaruh isi pesan terhadap perilaku konsumsi makanan produk Indofood pada masyarakat Desa Ngreden Kecamatan Wonosari Klaten.

2. Untuk menguji dan mengukur pengaruh format pesan terhadap perilaku konsumsi makanan produk Indofood pada masyarakat Desa Ngreden Kecamatan Wonosari Klaten.

3. Untuk menguji dan mengukur pengaruh sumber pesan terhadap keputusan pembelian makanan produk Indofood pada masyarakat Desa Ngreden Kecamatan Wonosari Klaten..

4. Untuk menguji dan mengukur pengaruh langsung visualisasi iklan terhadap keputusan pembelian makanan produk Indofood pada masyarakat Desa Ngreden Kecamatan Wonosari Klaten.

5. Untuk menguji dan mengukur visualisasi iklan dalam mediasi isi pesan, format, dan sumber iklan dampaknya terhadap keputusan pembelian makanan keputusan pembelian makanan produk Indofood pada masyarakat Desa Ngreden Kecamatan Wonosari Klaten.

\section{TINJAUAN PUSTAKA, KERANGKA PEMIKIRAN} DAN HIPOTESIS

\section{$>$ Tinjauan Pustaka}

1. Definisi Periklanan dan Televisi

Perusahaan berlomba-lomba membuat iklan untuk membangun posisi yang menguntungkan di pasar. Tapi sayang tidak banyak perusahaan yang membuat evaluasi mengenai efektivitas kegiatan promosinya melalui iklan secara tepat. Efektif tidaknya suatu iklan tergantung pada pencapaian tujuan pembuatan iklan itu sendiri, sehingga periklanan dapat dipandang sebagai kegiatan penawaran kepada suatu kelompok masyarakat baik secara lisan ataupun dengan penglihatan (berupa berita), tentang suatu produk, jasa, atau ide. Berita yang disampaikan tersebut dinamakan iklan atau advertensi (Sumber http:// www. angelfire.com/ id/akademika ; 2003). Kata iklan sendiri berasal dari bahasa yunani, yang artinya upaya menggiring orang pada gagasan. Adapun pengertian secara komprehensif atau luas adalah semua bentuk aktivitas untuk menghadirkan dan mempromosikan ide, barang ataupun jasa secara non-personal melalui media yang di bayar oleh sponsor tertentu, (Sumber : http://www.angelfire.com/id/akademika ; 2003). Pengertian lainnya, iklan adalah seni menyampaikan apa yang ditawarkan atau dijual untuk mendapatkan perhatian dan menempatkan produk secara unik kedalam pikiran konsumen dengan alat bantu (Roman, Maas \& Nisenholtz ; 2013).

Iklan merupakan sebuah proses komunikasi yang bertujuan untuk membujuk orang untuk mengambil tindakan yang menguntungkan bagi pihak pembuat iklan. Iklan ditujukan untuk mempengaruhi perasaan, pengetahuan, makna, kepercayaan, sikap, pendapat, pemikiran dan citra konsumen yang berkaitan dengan suatu produk atau merek, tujuan periklanan ini bermuara pada upaya untuk dapat mempengaruhi konsumen agar memberikan reaksi dan melakukan suatu tindakan seperti memutuskan dalam membeli sebuah produk atau jasa yang ditawarkan. Menurut Freddy Rangkuti (2014: 171), Iklan adalah salah satu cara untuk mengajarkan atau menginformasikan kepada orang- orang tentang produk kita. Melalui iklan ini kita dapat menginformasikan apa dan bagaimana produk kita tersebut, bagaimana produk itu dapat memenuhi kebutuhan konsumen, berapa harganya dan dimana produk tersebut dapat diperoleh. Iklan pun dapat menarik orang untuk datang melihat produk kita dan iklan dapat digunakan sebagai alat untuk mendifferensiasi produk serta mengembangkan citra (image) di benak konsumen. Iklan yang baik dapat menciptakan ketertarikan, persepsi yang baik dan citra yang baik, bahkan dapat mem-positioningkan suatu produk ditengah-tengah persaingan. Pengertian antara iklan dan periklanan mempunyai persamaan dan perbedaan. Persamaannya adalah bahwa keduanya merupakan pesan yang ditujukan kepada khalayak. Perbedaannya yaitu iklan lebih cenderung kepada produk atau merupakan hasil dari periklanan, sedangkan periklanan merupakan keseluruhan proses yang meliputi penyiapan, perencanaan pelaksanaan, dan pengawasan penyampaian iklan. Periklanan adalah suatu alat untuk membuka komunikasi dua arah antara 
penjual dan pembeli dengan segala macam bentuk komunikasi yang dibayar dimana sponsor maupun perusahaan diidentifikasi seperti televisi, radio, koran, majalah, buku, surat langsung, papan reklame, dan kartutransit, internet, computer dan mesin faximili.

adalah $\begin{array}{cr}\text { Salah satu keuntungan dari periklanan } \\ \text { kemampuannya }\end{array}$ mengkomunikasikan kepada sejumlah besar orang pada satu waktu. Iklan memiliki keunggulan untuk mampu menjangkau massa misalnya melalui jaringan televisi nasional, tetapi juga mungkin hanya menjangkau target yang sempit dari sejumlah calon pelanggan, seperti iklard. televisi melalui jaringan kabel yang ditargetkan atau melalui iklan cetak dalam majalah perdagangan (Sumber: http:// www.angelfire. com/id/akademika: 2003. Sedangkan menurut M. Suyanto (2012: 3), Periklanan merupakan penggunaan media bayaran oleh seorang penjual untuk meng- komunikasikan informasi persuasif tentang produk (ide, barang dan jasa) ataupun organisasi sebagai alat promosi yang kuat. Salah satu keuntungan utama periklanan lewat televisi adalah kemampuannya dalam membangun citra. Iklan televisi memiliki cakupan, jangkauan dan repetisi yang tinggi dan dapat menampilkan pesan multimedia (suara, gambar dam animasi) yang dapat mempertajam ingatan. Menurut M. Suyanto $(2012 ; 1)$, dijelaskan bahwa pengertian televisi adalah kombinasi dari gambar bergerak, suara dan kesegaran yang mengalami peralihan fungsi, awalnya sebagai media periklanan kemudian menjadi bidang permintaan penjualan perseorangan. Produk tidak hanya objek fisik, tetapi merupakan seperangkat manfaat atau nilai yang dapat memuaskan kebutuhan pelanggan baik secara fungsional, psikologis maupun sosial. Produk meliputi kualitas, keistimewaan, desain, gaya, keanekaragaman, bentuk, merek, kemasan, ukuran, pelayanan, jaminan dan pengembalian. Keunggulan elemen- elemen produk tersebut dapat membangun iklan.

Menurut M. Suyanto (2012: 39), Iklan televisi merupakan alat yang ampuh untuk menjaga kepemimpinan produk setelah kepemimpinan tersebut tercapai tetapi tidak untuk membangun merek. Selain itu juga iklan televisi merupakan alat bagi perusahaan yang ingin melindungi mereknya yang sudah kokoh. Iklan melalui televisi mempunyai dua segmen dasar yaitu penglihatan (visual) dan pendengaran (audio), misalnya : kata- kata, musik atau suara lain. Proses penciptaannya biasa di mulai dengan gambar karena televisi lebih unggul di dalam teknik gambarnya yang dapat bergerak. Di samping itu kata-kata dan suara juga harus diperhatikan.Media televisi adalah media yang dapat menampilkan pesan secara audiovisual dan gerak (sama dengan film). Kelebihan media televisi:

a. Jangkauan massal yang menimbulkan efisiensi biaya untuk menjangkau setiap kepala.

b. Pemirsa dapat diseleksi menurut jenis program dan waktu tayang.

c. Lebih menarik, berupa gambar bergerak dan mengandung suatu cerita.

Mempunyai kemampuan yang kuat untuk mempengaruhi persepsi khalayak sasaran

e. Calon pembeli lebih "percaya" pada perusahaan yang mengiklankan produknya di televisi daripada yang tidak sama sekali.

Ini adalah cerminan bonafiditas perusahaan.Kelemahan media televisi:

1). Sifat komunikasinya satu arah.

2) Gambarnya relatif kecil.

3) Siaran tidak bisa diulang sesuai keinginan sendiri.

\section{a. Fungsi dan Tujuan Periklanan}

Fungsi-fungsi periklanan antara lain :

1) Membantu memperkenalkan barang atau jasa baru dan kepada siapa atau dimana barang atau jasa itu dapat diperoleh.

2) Membantu dan mempermudah penjualan yang dilakukan oleh para penyalur.

3) Membantu salesman mengenalkan adanya barang atau jasa tertentu dan pembuatannya.

4) Meningkatkan volume penjualan.

5) Membantu ekspansi pasar.

Sementara periklanan media televisi yang berhasil dapat memberikan keuntungankeuntungan atau kelebihan- kelebihan, seperti :

1) Penghematan biaya.

2) Mampu mencapai atau menjangkau sasaran yang telah ditetapkan perusahaan sebelumnya secara luas.

3) Mempunyai dampak yang sangat kuat terhadap konsumen karena menekankan indera sekaligus yaitu indera penglihatan dan pendengaran.

4) Selalu mengingatkan kepada pembeli atau calon- calon pembeli.

5) Membentuk produk motivasi.

Di samping memiliki kelebihan, media televisi juga memiliki kelemahan- kelemahan sebagai media periklanan, di antaranya :

1) Jika periklanan tidak berhasil dan tidak berdampak pada peningkatan penjualan, maka 
biaya periklanan yang dikeluarkan akan terasa lebih mahal termasuk juga untuk biaya melakukan perubahan iklan.

2) Sulit melakukan segmentasi karena sasaran yang dijangkau tidak selektif, sebab acara televisi disaksikan oleh semua lapisan masyarakat yang memiliki karakteristik yang berbeda-beda.

Aspek pertama yang paling penting sebelum merumuskan strategi periklanan adalah sebuah sasaran atau tujuan. Tujuan itu tergantung pada apa yang ingin dicapai oleh perusahaan. Penetapan tujuan periklanan merupakan aspek penting yang mendapat perhatian serius. Tanpa tujuan yang baik, tidak mungkin mengarahkan dan mengendalikan keputusan dengan efektif dan efisien. Tujuan periklanan berfungsi sebagai alat komunikasi dan koordinasi, memberikan kriteria dalam pengambilan keputusan serta sebagai alat evaluasi. Menurut Basu Swastha (2011: 246), tujuan iklan di antaranya :

1) Memberikan informasi suatu produk kepada masyarakat.

2) Membujuk atau mempengaruhi masyarakat agar membeli dan menggunakan produk yang diiklankan. Iklan adalah usaha untuk mempengaruhi konsumen dalam bentuk tulisan, kata-kata, suara-suara atau kombinasi dari kesemuanya yang diarahkan kepada masyarakat.

3) Menciptakan kesan atau citra (image) suatu produk kepada masyarakat.

4) Dengan sebuah iklan orang akan mempunyai kesan tertentu tentang apa yang akan diiklankan. Dalam hal ini pemasang iklan selalu berusaha untuk menciptakan iklan yang sebaik-baiknya dengan penggunaan warna, bentuk dan penampilan yang menarik.

5) Untuk mengingatkan kepada masyarakat bahwa produk tersebut masih exist di pasaran. Iklan jenis ini sangat penting dalam tahap kedewasaan suatu produk untuk menjaga konsumen agar selalu ingat akan produk tersebut.

6) Sebagai alat komunikasi, dimana dalam hal ini komunikasi dapat terpenuhi dengan cara mengadakan pertukaran yang saling memuaskan.

Sedangkan menurut Durianto (2017), secara umum tujuan perusahaan mengiklankan produknya adalah dalam rangka :

1) Menciptakan kesadaran pada suatu merek di dalam benak konsumen. Brand awarness yang tinggi merupakan kunci untuk mencapai brand equity yang kuat. Para pemasar harus menyadari bahwa tanpa Brand awarness yang tinggi akan sulit untuk mendapatkan pangsa pasar yang tinggi.

2) Mengkomunikasikan informasi kepada konsumen mengenai keunggulan suatu merek. Manfaat ini berhubungan dengan keunggulan dari sebuah produk dibanding produk lain.

3) Mengasosiasikan suatu merek dengan perasaan serta emosi tertentu. Tujuannya, agar ada hubungan emosi antara konsumen dengan suatu merek.

4) Membuat perilaku, artinya perilaku konsumen dapat di bentuk melalui kampanye periklanan.

5) Mengembangkan atau mengubah citra atau personalitas dari sebuah merek. Sebuah merek terkadang mengalami keterpurukan di mata konsumen sehingga perlu diperbaiki citra atau image-nya yang dilakukan melalui periklanan.

6) Mengembangkan persepsi positif calon konsumen yang diharapkan kelak akan dapat menjadi pembeli potensial.

7) Mengarahkan konsumen untuk membeli produk.Dari sekian banyak tujuan perusahaan dalam periklanan seperti yang telah disebutkan di atas, hanya beberapa tujuan saja yang harus dipilih. Tujuan tersebut harus benar- benar sesuai dengan apa yang diinginkan perusahaan terhadap kampanye produknya. Semakin efektif dan efisien tujuan periklanan maka kemungkinan kampanye periklanan berhasil akan semakin terbuka.

Menurut M. Suyanto (2012: 53), Tujuan periklanan televisi dapat digolongkan menurut sasarannya yaitu untuk memberi informasi, persuasi, mengingatkan para pembeli, menambah nilai dan membantu aktivitas lain yang dilakukan perusahaan.

1) Periklanan Informatif (informative advertising) dimaksudkan sebagai tahap pelopor dari kategori produk untuk membangun permintaan awal atau membentuk permintaan pertama dengan cara :

a) Memberitahu pasar tentang satu produk baru dan membangun citra (image) perusahaan.

b) Menyarankan atau mengusulkan kegunaan baru dari suatu produk.

c) Menginformasikan pasar tentang perubahan harga

d) Menjelaskan pelayanan yang tersedia

e) Mengoreksi kesan yang salah, mengurangi kecemasan pembeli, dll

2) Periklanan Persuasif (persuasive advertising) dimaksudkan untuk membangun atau 
membentuk "permintaan selektif" untuk suatu brand tertentu, yang dilakukan pada tahap kompetitif dengan cara :

a) Membentuk preferensi merek

b) Mendorong alih merek

c) Mengubah persepsi pembeli tentang atribut produk

d) Membujuk pembeli untuk membeli sekarang

e) Mencoba produk yang ditawarkan.

Beberapa periklanan persuasif telah bergeser ke arah periklanan perbandingan (comparison adverting) yang bermaksud membangun superioritas satu brand melalui perbandingan spesifik dengan satu atau lebih brand lainnya dalam kelas produk yang sama.

3) Periklanan Pengingat (reminder advertising) dimaksudkan untuk mengingatkan pembeli dengan suatu produk yang sudah mature (mapan) bahwa produk tersebut mungkin akan dibutuhkan kemudian. Satu bentuk periklanan yang berhubungan dengan ini adalah periklanan penguatan (reinforcement advertising) yang menjamin pembelian yangsekarang pembeli lakukan adalah pilihan yang tepat. Contoh periklanan yang mengingatkan :

a) Mengingatkan pembeli bahwa satu produk akan diperlukan di masa mendatang.

b) Membuat pembeli tetap mengingat produk itu meskipun sedang tidak musim.

c) Mengingatkan pembeli tentang tempat membeli produk tersebut.

d) Periklanan Penambah Nilai dimaksudkan untuk menambah nilai merek pada persepsi konsumen dengan melakukan inovasi, perbaikan kualitas dan penguatan persepsi konsumen.

Iklan yang efektif akan menyebabkan merek dipandang lebih elegan, lebih bergaya, lebih prestisius dan mungkin super dalam persaingan. Elemen-elemen susunan iklan seperti ukuran, warna dan ilustrasi juga penting agar penikmat iklan bisa membedakan iklan tersebut dari iklan lainnya. Menurut penelitian, hal-hal yang paling penting dalam beriklan menurut urutannya adalah : gambar, headline dan isi atau tulisan iklan. Televisi dapat menentukan pemilihan target konsumen berdasarkan: wilayah geografis, waktu penyiaran, program yang akan ditayangkan dan jaringan. Melalui TV iklan dapat menampilkan kebanggaan dan kemewahan. Secara umum iklan yang ditayangkan melaui TV bersifat sangat intrusive, dimana pemirsa tidak perlu bersikap aktif, cukup duduk sambil melihat iklan yang ditayangkan.
Hanya satu tujuan periklanan, yaitu menjual produk atau jasa yang di iklankan, maka dari itu dalam menyusun iklan kita harus memperhatikan hal-hal yang mendukung agar iklan yang kita sampaikan sesuai dengan tujuan. Hal-hal tersebut antara lain:

a) Pengetahuan tentang produk dan jasa yang di iklankan, sekaligus juga pengetahuan tentang produk pesaingnya (kompetitor)

b) Mengetahui kekuatan (strength) dan kelemahan (weakness) produk atau jasa yang akan diiklankan dibandingkan dengan para pesaingnya.

c) Yakin dengan barang atau jasa yang dikeluarkan.

Kemudian ada 5 (lima) keputusan dalam program periklanan yang disebut juga dengan program $5 \mathrm{M}$, antara lain :

(1) Mission (misi) yaitu tujuan dari periklanan.

(2) Money (uang) yaitu besarnya pengeluaran untuk periklanan.

(3) Message (pesan) yaitu pesan apa yang akan disampaikan.

(4) Media (media) yaitu media apa yang seharusnya digunakan.

(5) Measurement (pengukuran) yaitu bagaimana seharusnya hasil periklanan itu evaluasi.

b. Pesan Iklan

Menurut M. Suyanto (2012 ; 68), Strategi merancang pesan membutuhkan strategi kreatif dengan melewati tahap pembentukan, evaluasi, seleksi dan pelaksanaan pesan. Iklan harus dapat disampaikan secara kreatif, bahkan kreativitas lebih penting dari pada jumlah uang yang dikeluarkan.Pesan juga harus menginformasikan kekhususannya yang tidak ada dalam barang (serupa) merek lain dan pada akhirnya pesan harus bisa dipercaya. Pengaruh pesan tidak hanya tergantung pada apa yang diutarakannya saja, melainkan juga bagaimana cara mengutarakannya. Para pembuat iklan harus mengutarakan pesannya demi meraih perhatian dan keinginannya khalayak yang ditargetkan. Mereka yang kreatif dapat menyajikan pesannya dalam berbagai gaya yang berbeda, seperti:

1) Bagian kehidupan (Slice of life)

Gaya dimaksudkan memperlihatkan seseorang atau orang-orang yang menggunakan atau memakai barang tertentu dalam kehidupannya.

2) Gaya hidup (Life style) 
Gaya ini melukiskan bagaimana suatu barangc. Jenis- Jenis Iklan

cocok dengan suatu gaya hidup.

3) Khayalan (Fantasy)

Gaya tersebut menciptakan suatu khayalan tentang barang atau penggunanya.

4) Suasana hati (Mood)

Image (mengesankan) gaya ini membentuk suatu keadaan jiwa atau suasana yang mengesankan tentang barang atau ketenangannya.

5) Bernuansa musik (Musical)

Gaya demikian memperlihatkan seseorang atau orang yang sedang menyanyikan sebuah lagu yang melibatkan barang yang ditawarkannya.

6) Simbol pribadi (Personality symbol)

Gaya dimaksudkan membentuk karakter yang melambangkan kualitas suatu barang.

7) Teknisi (Technical expense)

Gaya tersebut memperlihatkan keahlian teknis suatu perusahaan atau orang- orang dengan pengalamanya membuat dan menghasilkan suatu barang.

8) Bukti ilmiah (Scientific eveidence)

Gaya ini menyajikan hasil survei atau bukti ilmiah bahwa merek ataupun barangnyalebih dapat dipercaya khasiatnya dibandingkan merek atau barang lain.

9) Buat penghargaan (Testimonial evidence)

Keistimewaan untuk bisa dipercaya dan dapat menyenangkan merupakan sumber bantuan bagi penjualan suatu barang.

Daya tarik pesan dapat diciptakan dengan menggunakan selebritis, humor, rasa takut, kesalahan, musik dan komparatif. Kita dapat membuat produk atau merek menjadi menonjol dalam periklanan, salah satunya dengan menggunakan daya tarik para figure masyarakat, seperti seorang bintang TV, actor, actris, atlit, ilmuwan, dsb. Selebritis adalah pribadi yang di kenal masyarakat untuk mendukung suatu produk, selebritis juga merupakan juru bicara produk. Merancang slogan atau tagline yang tertuang dalam pesan iklan televisi merupakan awal dari kesuksesan periklanan. Slogan menjadi pernyataan standar yang mudah diterima di benak konsumen. Sedangkan logo merupakan suatu identitas merek yang mengkomunikasikan secara luas tentang produk, pelayanan, dan organisasi dengan cepat. Logo bukan sekedar suatu label tetapi dapat menampilkan pesan kualitas dan semangat produk melalui pemasaran, periklanan dan kinerja produk. Logo juga harus bersifat unik, mudah diingat dan mudah dikenali.

Iklan yang sering muncul diberbagai media dan umumnya dibuat oleh perusahaan periklanan adalah sebagai berikut:

1) Iklan Komersial

Iklan yang bertujuan untuk mendukung kampanye pemasaran suatu produk atau jasa. Iklan komersial ini sendiri terbagi menjadi beberapa macam (Lwin \& Aitchinson ; 2011), yaitu :

a) Iklan Strategis

Digunakan untuk membangun merek. Hal itu dilakukan dengan mengkomunikasikan nilai merek dan manfaat produk. Perhatian utama dalam jangka panjang adalah memposisikan merek serta membangun pangsa pikiran dan pangsa pasar. Iklan ini mengundang konsumen untuk menikmati hubungan dengan merek serta meyakinkan bahwa merek ini ada bagi para pengguna.

b) Iklan Taktis

Memiliki tujuan yang mendesak. Iklan ini dirancang untuk mendorong konsumen agar segera melakukan kontak dengan merek tertentu. Pada umumnya iklan ini memberikan penawaran khusus jangka pendek yang memacu konsumen memberikan respon pada hari yang sama.

2) Iklan Corporate

Iklan yang bertujuan membangun citra suatu perusahaan yang pada akhirnya diharapkan juga membangun citra positif produk-produk atau jasa yang diproduksi oleh perusahaan tersebut (Madjadikara; 2004). Iklan Corporate merupakan bentuk lain dari iklan strategis ketika sebuah perusahaan melakukan kampanye untuk mengkomunikasikan nilainilai korporatnya kepada publik (Lwin \& Aitchison ; 2005).

3) Iklan Layanan Masyarakat

Merupakan bagian dari kampanye sosial marketing yang bertujuan menjual gagasan atau ide untuk kepentingan atau pelayanan masyarakat (Madjadikara ; 2004).

\section{d. Rumus AIDCA Dalam Periklanan}

Dalam pembuatan iklan, untuk menghasilkan iklan yang baik maka harus menggunakan elemen-elemen dalam sebuah rumus yang dikenal sebagai AIDCA yang terdiri dari :

1) Attention (perhatian), dimana iklan harus dapat menarik perhatian khalayak sasarannya dengan menggunakan tagline yg menarik dan slogan yang mudah di ingat. 
2) Interest (minat), dimana perhatian harus dapat segera ditingkatkan menjadi minat sehingga timbul rasa ingin tahu lebih rinci di dalam diri calon pembeli.

3) Desire (kebutuhan atau keinginan), dimana kebutuhan atau keinginan mereka untuk memiliki, memakai atau melakukan sesuatu harus dibangkitkan.

4) Conviction (rasa percaya), dimana dalam menimbulkan rasa percaya diri calon pembeli, maka sebuah iklan dapat ditunjang dengan berbagai kegiatan peragaan seperti testimonial atau pembuktian, membagibagikan percontohan produk secara gratis.

5)Action (tindakan), dimana dalam membujuk calon pembeli agar segera melakukan suatu tindakan pembelian. Mulai dari tahap percobaan keputusan dan konfirmasi.

\section{e. Kekuatan Iklan Televisi}

Iklan televisi adalah „media" pemilik produk yang diciptakan oleh biro iklan, kemudian iklan televisi disiarkan televisi dengan berbagai tujuan, diantaranya adalah sebagai informasi produk dan mendorong penjualan. Oleh karena itu iklan televisi harus memiliki segmen berdasarkan pilihan segmen produk. Segmen ini ditentukan untuk memilih strategi media, agar iklan sampai pada sasaran (Bungin, 2008:40). Televisi memiliki berbagai kelebihan dibandingkan dengan jenis media lainnya yang mencakup daya jangkau luas, selektivitas dan fleksibilitas, fous perhatian, kreativitas dan efek, prestise, serta waktu tertentu. Kita akan meninjau kelebihan iklan televisi tersebut satu per satu.

Daya Jangkau Luas. Penetrasi televisi dewasa ini sudah sangat luas, khususnya televisi yang bersiaran secara nasionaol. Harga pesawat televisi yang semakin murah dan daya jangkau siaran yang semakin luas menyebabkan banyak orang yang sudah dapat menikmati siaran televisi. Siaram telvisi saat ini sudah dinikmati oleh berbagai kelompok masyarakat. Daya jangkau siaran yang luas ini memungkinkan pemasar memperkenalkan dan mempromosikan produk barunya secara serentak dalam wilayah yang luas bahkan ke seluruh wilayah suatu Negara.

\section{Keputusan Pembelian}

\section{a. Pengerian}

Pengertian Keputusan Pembelian Menurut Kotler \& Keller (2016: 184) Keputusan pembelian adalah proses integrasi yang digunakan untuk mengombinasikan pengetahuan untuk mengevaluasi dua atau lebih perilaku alternatif dan memilih satu di antaranya. Keputusan konsumen adalah sebuah pendekatan penyelesaian masalah pada kegiatan manusia untuk membeli suatu barang atau jasa dalam memenuhi keinginan dan kebutuhannya.

b. Proses Pengambil Keputusan

Menurut Kotler \& Keller (2016: 184) proses pengambil keputusan adalah sebuah pendekatan penyesuaian masalah yang terdiri dari lima tahap yang dilakukan konsumen, kelima tahap tersebut adalh pengenalan masalah, pencarian informasi, evaluasi alternatif, membuat keputusan, dan perilaku pasca Pembelian

Gambar .1

Tahap Proses Keputusan Pembeli

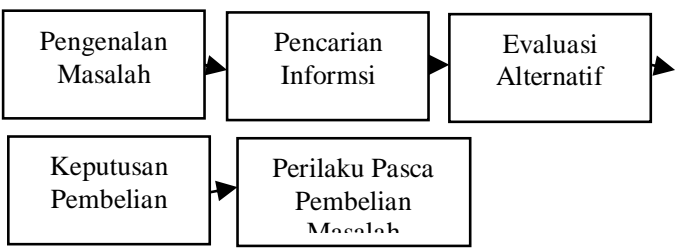

1) Pengenalan masalah. Pengenalan masalah adalah proses pembelian dimulai ketika pembeli menyadari suatu masalah atau kebutuhan yang dipicu oleh rangsangan internal atau eksternal. Jika kebutuuhan diketahui maka konsumen akan serta memahami kebutuhan yang belum perlu segera dipenuhi atau masalah dapat ditunda pemenuhannya, serta kebutuhan yang sama-sama harus segera dipenuhi. Jadi, pada tahap inilah proses pembelian mulai dilakukan.

2) Pencarian informasi Pencarian informasi adalah tahap proses pengambilan keputusan pembeli dimana konsumen telah tertarik untuk mencari lebih banyak informasi konsumen mungkin hanya meningkatkan perhatian atau mungkin aktif mencari informasi. 3) Evaluasi alternatif Evaluasi alternatif adalah tahap dalam proses pengambilan keputusan dimana pembeli dimana konsumen menggunakan informasi untuk mengevaluasi berbagai penyedia jasa alternatif pilihan. 4) Keputusan Pembelian Keputusan pembelian adalah kegiatan individu yang secara langsung terlibat dalam pengambilan keputusan untuk melakukan pembelian terhap produk yang ditawarkan oleh penjual. 5) Perilaku Pasca Pembeli Perilaku pasca pembeli adalah konsumen tersebut juga akan terlibat dalam tindakantindakan sesudah pembelian dan penggunaan produk atau jasa yang akan menarik minat pemasar. Pekerjaan pemasar tidak akan berakhir pada saat suatu jasa dijual, tetapi akan terus berlangsung hingga periode sesudah pembelian 
supaya konsumen bisa melakukan keputusan pembelian ulang.

\section{Kerangka Pemikiran}

Untuk lebih jelasnya dan tidak menyimpang dari pembahasan, maka dapat penulis gambarkan dalam kerangka pemikiran sebagai berikut:

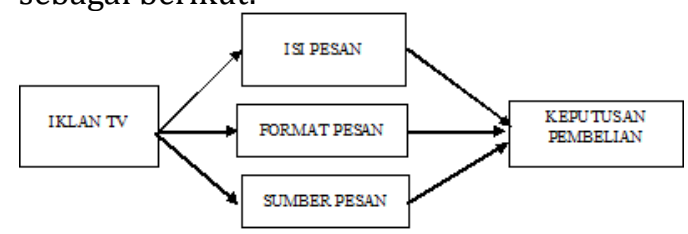

Gambar 2

Kerngka Pemikiran

\section{Hipotesis}

Di dalam penelitian ini, penulis mencoba untuk menganalisa dengan membuat hipotesis yaitu :

1. Terdapat pengaruh isi pesan terhadap Keputusan Pembelian Makanan "Produk Indofood" Pada Masyarakat Desa Ngreden Kecamatan Wonosari Klaten

2. Terdapat pengaruh format pesan terhadap Keputusan Pembelian Makanan "Produk Indofood" Pada Masyarakat Desa Ngreden Kecamatan Wonosari Klaten.

3. Terdapat pengaruh sumber pesan terhadap Keputusan Pembelian Makanan "Produk Indofood" Pada Masyarakat Desa Ngreden Kecamatan Wonosari Klaten.

4. Faktor isi pesan paling dominan pengaruhnya terhadap Keputusan Pembelian Makanan "Produk Indofood" Pada Masyarakat Desa Ngreden Kecamatan Wonosari Klaten

Faktor-faktor yang Mempengaruhi Keputusan Pembelian.Terdapat faktor internal dan eksternal konsumen yang berpengaruh dalam melakukan keputusan pembelian. Peran faktorfaktor tersebut berbeda untuk produk yang berbeda. Dengan kata lain, ada faktor yang dominan pada pembelian produk, sementara faktor lain kurang berpengaruh.

\section{METODE PENELITIAN}

1. Ruang Lingkup Penelitian

Penelitian ini dilakukan di Wilayah Desa Ngreden Kecamatan Wonosari Klaten. Adapun yang menjadi subyek dalam penelitian ini adalah masyarakat pengkonsumsi produk Indofood. Alasan penulis melakukan obyek dan subyek pada masyarakat pengkonsumsi Mie Instan di Wilayah t Desa Ngreden Kecamatan Wonosari Klaten. belum pernah dilakukan penelitian khusunya yang berkaitan dengan masalah Pengaruh Visualisasi Iklan TV Terhadap Keputusan Pembelian Makanan "Produk Indofood" Pada Masyarakat Desa Ngreden Kecamatan Wonosari Klaten.

\section{Populasi dan Sampel}

Dalam penelitian ini yang menjadi populasi penelitian adalah masyarakat di Desa Ngreden Kecamatan Wonosari Klaten sebanya 2.100 orang.

Menurut Cooper dan Schindler (2016) jumlah sampel yang diambil dapat dipilih sebagai sampel adalah 96 orang dan dalam penelitian ini dibulatkan menjadi 100 orang.

4. Sumber Data

Dalam penelitian ini penulis menggunakan dua sumber data yaitu:
a. Data Primer
b. Data Sekunder

5. Teknik Pengumpulan Data
a. Kuesioner
b. Interview
c. Studi Pustaka

6. Teknik Analisis Data

a. Uji Instrumen Penelitian (Validitas dan Reliabilitas)

b. Uji Asumsi Klasik

c. Analisis Regresi Linier Berganda

d. Pengujian Hipotesis

7. Hasil Analisis Data

a. Hasil uji Instrumen Penelitian

Berdasarkan pada uji instrumen penelitian yang terdiri dari uji validitas dan uji reliabilitas diketahui bahwa tiap item pertanyaan valid dan reliabel memenuhi syarat untuk pengumpulan data

b. Hasil uji Prasyarat Analisis/ Uji asumsi klasik

Telah lolos uji prasyarat analisis oleh karena itu layak untuk memprediksi analisis berikutnya.

\section{c. Hasil Uji Regresi Model Causal Step}

Tabel 1 


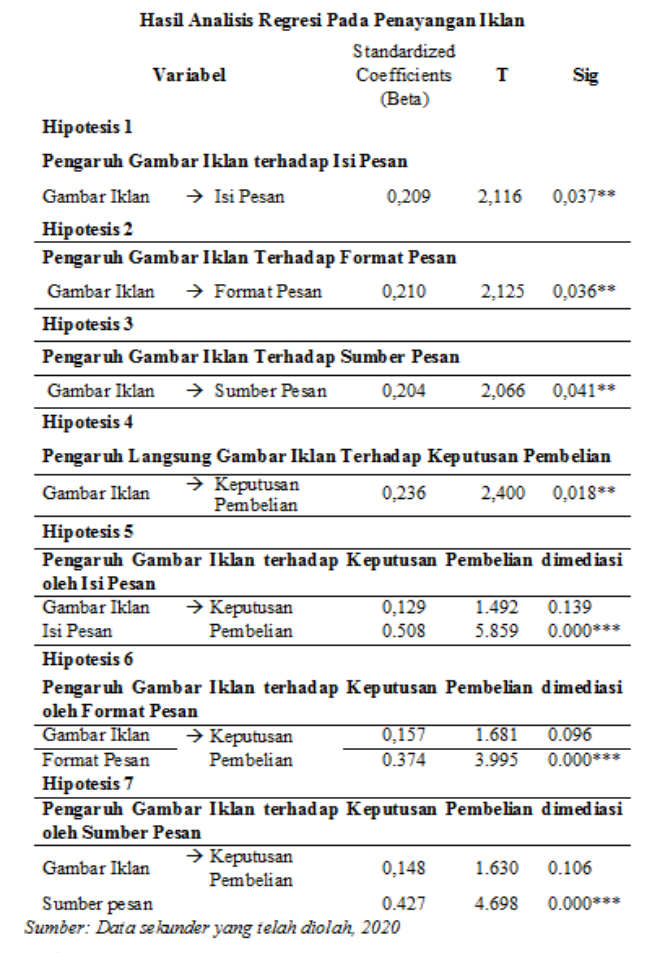

HASIL PENELITIAN

Hasil pengujian hipotesis dengan menggunakan analisis Jalur dengan variabel bebas visualisasi iklan yang dimediasi oleh isi pesan, format pesan dan sumber pesan dan satu variabel terikat keputusan pembelian konsumen menunjukkan bahwa:

1.Visualisasi iklan di TV berpengaruh terhadap isi pesan, format pesan dan sumber pesan tentang makanan produk Indofood pada masyarakat Desa Ngreden Kecamatan Wonosari Klaten.

2.Isi pesan iklan memediasi pengaruh visulaisasi iklan terhadap keputusan pembelian makanan produk Indofood pada masyarakat Desa Ngreden Kecamatan Wonosari Klaten. Mediasi pengaruh isi pesan terhadap visualisasi iklan bersifat semperuna (full mediasi).

3. Format pesan memediasi pengaruh visulaisasi iklan terhadap keputusan pembelian makanan produk Indofood pada masyarakat Desa Ngreden Kecamatan Wonosari Klaten. Mediasi pengaruh format pesan terhadap visualisasi iklan bersifat semperuna (full mediasi).

4. Sumber pesan memediasi pengaruh visulaisasi iklan terhadap keputusan pembelian makanan produk Indofood pada masyarakat Desa Ngreden Kecamatan Wonosari Klaten. Mediasi pengaruh dari sumber pesan terhadap visualisasi iklan bersifat semperuna (full mediasi).

5. Isi pesan mempunyai dampak hubungan paling kuat dengan keputusan pembelian, sedangkan dampak yang paling lemah adalah sumber pesan.

\section{DAFTAR PUSTAKA}

Agung Nugroho, (2015). Strategi Jitu memilih Metode statistic Penelitian dengan SPSS, Yogyakarta: Andi.

Anwar Prabu Mangkunegara, (2013). Manajemen Sumber Daya Manusia Perusahaan, Jakarta : Remaja Rosdakarya.

Azry, Muhammad. 2016. Pengaruh Iklan Televisi Terhadap Keputusan Pembelian di Situs Bukalapak.com. Universitas Telkom, Bandung.

Basu Swastha. (2011). Manajemen Pemasaran. Edisi Kedelapan. Cetakan Kedelapan. Jakarta: Penerbit Liberty.

Bilson Simamora, (2013). Panduan Riset Perilaku Konsumen, Jakarta; PT Gramedia Pustaka Utama,

Cooper, Donald R dan Schindler, Pamela S. (2016). Marketing Research. New York: McGrawHill.

Dimas Yanuar Miftahudin, (2012). Analisia Pemetaan Persepsi Pelanggan Produk Mie Instan Di Kota Bandung Tahun 2012 (Studi Kasus Pada Produk Mie Instan Merek Indomie, Mie Sedaap, Supermi, dan Sarimi). Bandung: STT Telkom,

Durianto, Darmadi, (2017), Strategi Menaklukkan Pasar Melalui Riset Ekuitas dan Perilaku Merek, Cetakan XX, Jakarta: PT. Gramedia Pustaka Utama.

Eddy Herjanto. (2006). Manajemen Operasi. edisi ketiga. Jakarta. GRASINDO.

Eko Wahyu Widayat (2012) Pengaruh Merek, Iklan Dan Kualitas Produk Terhadap Keputusan Membeli Mie Instan Supermi (Studi Kasus Pada Masyarakat Kelurahan Tanah Seribu Kecamatan Binjai Selatan, Binjai). Jurnal Keuangan dan Bisnis Vol. 4 No. 2, Juli 2012 
Fandy Tjiptono, (2014) Pemasaran Jasa, Edisi Kelima, Yogyakarta: Andi Offset.

Gujarati Damodar, (2012), Basic Econometrics, $5^{\text {th }}$ Edition, Mc Graw - Hill,Inc. New York.

Herdyta Abdi Ilmasari dan Asidigisianti Surya Patria (2016) Analisis Struktur dan Makna Visual Iklan Indomie Versi Nicholas Saputra.. Jurnal Pendidikan Seni Rupa, Volume, 04, Nomor, 01, Tahun, 2016, 106-114.

Lwin, May., \& Aitchison, Jim. (2011). Clueless in Advertising; Pengalih Bahasa, Paul A, Rajoe. Jakarta: Bhuana Ilmu Populer.

Lupiyoadi, Rambat., 2013. Manajemen Pemasaran Jasa Berbasis Kompetensi (Edisi 3). Jakarta: Salemba Empat.

Madziatul Churiyah dan Diarci Hagayuna (2007). Faktor-Faktor Yang Menentukan Perilaku Pembelian Mi Instan Merek Sedaap. MODERNISASI, Volume 3, Nomor 3, Oktober 2007

Morissan, (2018). Periklanan: Komunikasi Pemasaran Terpadu, Jakarta: Prenada Media Group.

M.suyanto. (2012). Pengantar Teknologi infomasi untuk bisnis.Yogyakarta: Andi.

Kotler, Philip (2012). Manajemen Pemasaran, Analisis, Perencanaan, Implikasi, dan Pengendalian, Buku Satu, Edisi Sepuluh, diIndonesiakan oleh Ancella Anitawati Hermawan, Jakarta : Penerbit Salemba Empat.

Kotler, Philip dan Kevin Lane Keller, 2016. Marketing Management. Edisi 15, Global Edition United Kingdom: Pcarson Education.

Sekaran, Uma. (2016) Metode Penelitian untuk Bisnis.Jilid 1.Edisi 4. Jakarta: Salemba Empat.

Suharsimi, Arikunto, (2016). Prosedur Penelitian : Suatu Pendekatan Praktik, Jakarta, PT Bina Aksara.
Sutisna. (2010) Manajemen Pemasaran. Edisi Kesebelas. Jakarta : Indeks

Rangkuti, Freddy (2014). Measuring Customer Satisfaction Teknik Mengukur dan Strategi Meningkatkan Kepuasan Pelanggan dan Analisis Kasus PLN-JP. Jakarta:PT. Gramedia Pustaka Utama

Roman, Kenerth, Jane Maas \& Martin Nisenholtz, (2013). How To Advertise, Membangun Merek dan Bisnis dalam Dunia Pemasaran Baru. Jakarta: PT. Elex Media Komputindo.

Tunggal, Amin Wijaya. (2005). Branding. Jakarta: Rineka Cipta

http://www.angelfire.com/id/akademika ; 2016.

Sulaksana, Uyung. (2014). Integrated Marketing Communications Teks dan Kasus. Yogyakarta: Pustaka Pelajar

Teguh Budiarto dan Fandy Ciptono. (2014). Pemasaran Internasional. Edisi Pertama. Yogyakarta: BPFE-UGM.

Thoyibie, Lafif. (2019). Peranan Public Relations. Http//:Komunikasi.Indonesia. Org/ Peranan Public Relations.

Tunggal,Amin Wijaya (2019), Manajemen Kontenporer, Buku 2, Jakarta: Harvarindo

Wenny Kartika Susanto dan Keni (2018). Pengaruh Social Network Marketing (SNM) Dan Electronic Word of Mouth (Ewom) Terhadap Minat Beli Pelanggan. Jurnal Manajemen Bisnis Dan Kewirausahaan/ Volume 02/No.6/ November-2018 : 68-73

Yuliansyah, 2019. Meningkatkan Respon Rate pada Penelitian Survey. Suatu Studi Literatur. Jakarta: Smart, Imprint Change Publication. 